\title{
Social and Economic Factors Associated with the Consumption of Alcoholic Beverages in Universities
}

\author{
Gabith M. Quispe Fernandez ${ }^{1,2}$, Vicente Marlon Villa Villa ${ }^{1}$, Otto Eulogio Arellano Cepeda ${ }^{1}$, Dante Ayaviri Nina ${ }^{2,3}$ \\ \& Rodrigo Velarde Flores ${ }^{1}$ \\ ${ }^{1}$ School Accounting and Auditing, National University of Chimborazo, Ecuador \\ ${ }^{2}$ School of Business Administration, Technical University of Oruro, Bolivia \\ ${ }^{3}$ Commercial Engineering and Economics School, National University of Chimborazo, Ecuador \\ Correspondence: Dante Ayaviri Nina, Campus Norte “Edison Riera R.”, Av. Antonio José de Sucre Km 1/1/2 vía \\ Guano, Riobamba city, Ecuador.
}

Received: June 12, 2019

Accepted: July 30, 2019 Online Published: October 25, 2019

doi:10.5539/ies.v12n11p111

URL: https://doi.org/10.5539/ies.v12n11p111

\begin{abstract}
The objective of the research is to determine the social and economic factors associated with the consumption of alcoholic beverages and their impact on professional training through the fulfillment of academic activities of university students. It uses the deductive method, and has a descriptive level (factorial and discriminant analysis) and explanatory level (regression analysis). The questionnaire was applied as a data collection instrument, which has an index of Cronbach's alpha of 0.745. It is applied to a sample of 98 students from a total population of 9,194 from the National University of Chimborazo, Ecuador. The results show that the alcohol consumption in university students depends significantly on the age that begins to consume, gender, marital status and frequency of consumption; there are social and economic factors associated with alcohol consumption; a high incidence of alcohol consumption in compliance with academic obligations in the professional training process.
\end{abstract}

Keywords: social factors, economic factors, academic activities, alcohol consumption, academic obligations, students

\section{Introduction}

Alcoholism is a problem not only of the adult segment, but also of the young population, being this different from that of the adult, since:

The negative effects usually refer to alterations in relationships with the family, classmates and teachers, poor school performance, aggression, violence, disturbance of public order and high-risk behaviors, such as driving after drinking, as well as unprotected sexual activities, which entail unwanted pregnancies and sexually transmitted diseases (Pediatrics, 1995). In general, students who drink large amounts of alcohol, compared to those who do not drink, exhibit riskier behaviors for themselves and others (Hingson, Heeren, \& Winter, 2006, cited in Castaño \& Calderon, 2014, p. 740).

Thus, alcoholism is not only a problem of the adult population but also of the young population, because according to the to the World Health Organization, "alcoholism is a behavioral disorder manifested by the uncontrolled consumption of alcoholic beverages, which It interferes with the mental, physical, social and/or family health of the drinker" cited in (Albarracin \& Muñoz, 2008, p. 50). In addition, it is considered that there is an increase in the number of consumers; which means, that alcoholism has become a public health problem; "because it is not only about producing health effects but also socially and academically, as mentioned by Donovan and Olsen (2007) quoted in (Albarracin \& Muñoz, 2008, p. 50). He also mentions that, "the academic, family and social difficulties caused by the abuse in question are added to the above" (Albarracin \& Muñoz, 2008, p. 51). It becomes an index of absenteeism, dropout and academic mortality rates, especially in the early years of the career, undertaken as part of its management, monitoring, analysis and monitoring of the university world" (Albarracin \& Muñoz, 2008, p. 51).

From this perspective, after a literature review it is identified that the research conducted on alcohol consumption in university students, addressed: the impact, causes, factors and the relationship with performance, such as those developed by Vargas-Martínez, Trapero-Bertran, Gil-García, and Lima-Serrano (2018), Vila (2018), López and Morales (2018), Sánchez (2018), Betancourth, Tacán, and Cordoba (2017), Rodríguez (2017), Míguez and Permuy 
(2017), López-Vásquez et al. (2017), Rubio (2016), Del Pino and Correa (2016), among others, as presented in the Table 1 .

Table 1. Studies carried out

\begin{tabular}{|c|c|c|}
\hline Author & Title of the investigation & Conclusion \\
\hline $\begin{array}{l}\text { (Vargas-Martínez, Trapero-Bertran, } \\
\text { Gil-García, \& Lima-Serrano, 2018) }\end{array}$ & $\begin{array}{l}\text { Impact of excessive } \\
\text { episodic } \\
\text { consumption } \\
\text { adolescence. Are we doing } \\
\text { it right? }\end{array}$ & $\begin{array}{l}\text { In Spain there are gaps in information on the harmful impacts of alcohol } \\
\text { consumption, especially in estimating their burden on mortality and } \\
\text { disease, the prevalence of alcohol use disturbances, social consumption } \\
\text { values and the effectiveness of alcohol abuse. the preventive programs. }\end{array}$ \\
\hline
\end{tabular}
it right?

(Vila, 2018, pp. 139-140)

Cognitive performance in adolescents with alcohol and internet abuse.

Adolescents with intensive alcohol consumption and those who do not show problematic Internet use do not have differences in cognitive performance.

Young people with problematic internet use and with intensive alcohol consumption show a similar performance in tasks of cognitive interest.

(López \& Morales, Consumo de Tobacco and alcohol tabaco y alcohol en estudiantes universitarios de enfermería de una institución pública del estado de Puebla, México, 2018) consumption in university nursing students of a public institution in the state of Puebla, Mexico.

Resilient behavior and alcohol abuse in Psychology students of the UMSA.

Nursing students have impressive prevalence of tobacco and alcohol consumption, begin to consume before 15 years of age, the average drink is 3.7 and the type of consumption is sensible. It is necessary to carry out preventive mediations and control of health in the university context.

University students with the highest consumption of risky and harmful alcohol range between 25 and 28 years of age, the male sex predominates. It can be affirmed that psychology students who develop more their resilient behavior have less abuse and alcohol consumption, students show a level of resilience higher than the average range, that is, a large percentage of them have developed the capacity to recover from hostile environments, especially the female sex.

The levels of alcohol consumption are maintained over time and it is necessary that universities worry about a comprehensive education that

(Betancourth, Tacán, \& Cordoba, Consumo de alcohol en estudiantes universitarios colombianos, 2017)

Alcohol consumption in Colombian university students. allows reducing alcohol consumption. The university must improve efforts in the difference of groups according to their particular characteristics according to their faculty, program and semester.

University students present two forms of consuming alcohol: an

Explanatory factors and consequences of alcohol consumption in university students.

(Rodríguez, 2017,p. 95)

Characteristics of alcoholism in women. intensive consumption whose peak reaches in women at 18 years, while in men it is at 22 years old and the other risk consumption whose preferred area is at 20 years Both men and women. The intensive consumption of alcohol presents risk factors such as: the practice of unsafe sex, traffic accidents and injuries due to alcohol.

Women initiate alcohol consumption at a later age. Among the risk factors for consumption we have: traumatic events including child abuse and sexual abuse, the relationship with an alcoholic partner, the prevalence of depressive signs, anxiety and the minimum use of health care services.

Reasons and types of Nursing university students, despite being future health experts, are not

(López-Vásquez, 2017) alcohol consumption in university nursing students.

Alcohol consumption and

(Rubio, 2016, pp. 157-159) developmental contexts in adolescence.

Alcoholism in university students of different careers. free from addictions; they show a memory, a weakness and a danger around the consumption of alcohol.

It has been observed a high prevalence and a progressive increase of drunkenness and alcohol consumption in women as in men. The danger of getting drunk is related to alcohol consumption, while the high risk observed is inversely related to its use

Male college students over 24 years of age who work often drink alcohol excessively. The causes are the emotional problems caused by their interpersonal actions.

Source: Own elaboration based on authors cited. 
In the case of Ecuador, alcoholism is a problem that is having an impact on university students; According to the latest National Health and Nutrition Survey 2011-2013, the Ministry of Health - National Institute of Statistics and Census, shows:

That $45.6 \%$ of adolescents between the ages of 10 and 19 declare that they have ever consumed beverages containing alcohol. For the group of 10 to 14 years is $21.3 \%$, while for the group of 15 to 19 years is $71.7 \%$. The ethnic groups with the highest prevalences are self-defined Afro-Ecuadorians (49.5\%) followed by mestizos, whites and others (47.4\%). Among those participants who reported having consumed alcohol at some time, $25.2 \%$, also reported on alcohol consumption in the 30 days prior to the survey (in men it is $32.4 \%$ and in women $17.1 \%$ ). For the group of 10 to 14 years it is $9.9 \%$, while for the group of 15 to 19 years it is $30 \%$ (Freire et al., 2013, p. 72).

Also, the data shows that the consumption in the population of 20 to 59 years is $41.3 \%$ (56.55\% in men and $25.4 \%$ in women) on average days of consumption is 1.9 days in men and 1.4 days in women. And people who consume alcohol mention that their consumption began 39.4\% between 14 to 15 years as shown in graph 1 , and in general $5 \%$ of the population consumes alcohol two or more days a week and $1 \%$ with greater or equal to four days. So, this problem affects the university community mainly university students in the different universities of the Republic of Ecuador. The study carried out by Alban (2016, p. 561) shows that there is "a relationship between the consumption of alcohol with the level of academic performance in the students of the School of Psychology of the Faculty of Legal, Social Sciences and the Education of the Technical University of Babahoyo"; which means that there are few studies that analyze why the university population in Ecuador consumes alcohol? What are its effects or consequences? What factors affect consumption? which means that it is important to know aspects related to this population to know what is the impact of alcohol consumption on learning processes, mainly in the fulfillment of academic duties, since this affects the professional training of the student and the type of employment of the future professional in the labor market.

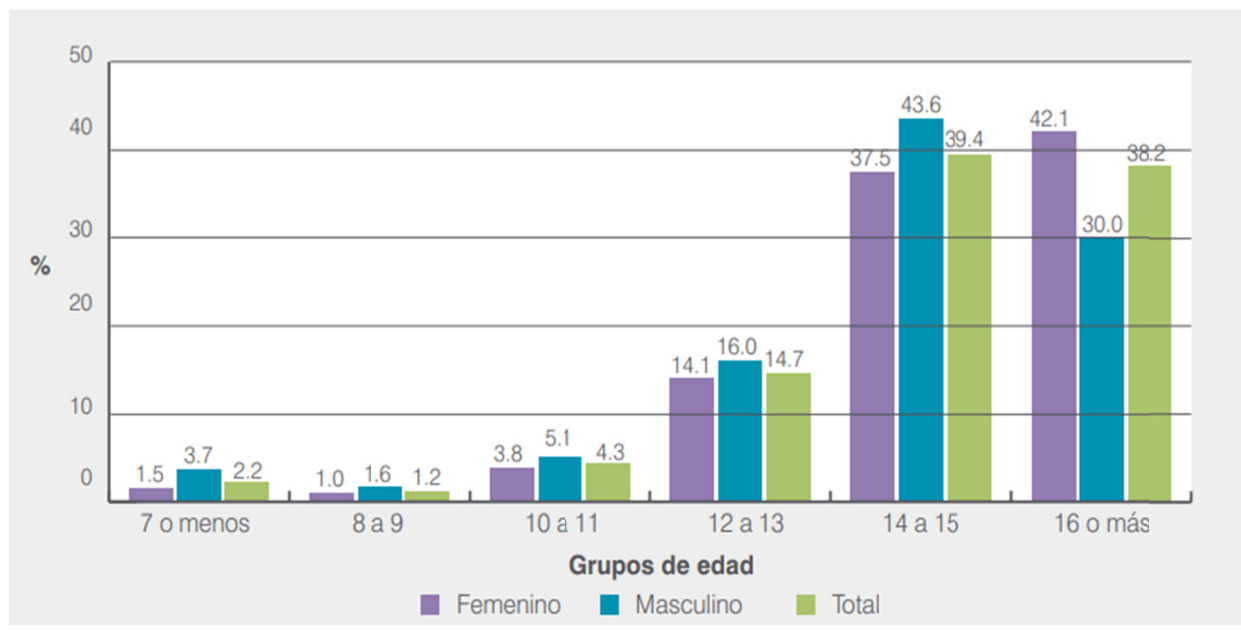

Figure 1. Age of onset of alcohol consumption, population from 10 to 19 years at national level, by sex (Source: Freire et al., 2013, p. 74)

These antecedents allow posing questions with which the present investigation work. What are the social or economic factors that determine the consumption of alcohol in university students? How does alcohol consumption affect the professional training of university students?

There are different explanations to these questions; However, the research responds through the following hypotheses: $\mathrm{H} 1$ the alcohol consumption in university students depends significantly on the age that begins to consume, gender, marital status and frequency of consumption; H2 there are social and economic factors associated with alcohol consumption; H3 there is a high incidence of alcohol consumption in compliance with academic obligations in the process of professional training; Likewise; and $\mathrm{H} 4$ factors such as: the frequency cannot stop drinking alcohol, guilt for consuming alcohol and those who have a preferred alcoholic beverage are factors that determine the non-compliance of economic activities. 
Therefore, the objective of the research is to determine the social and economic factors associated with the consumption of alcoholic beverages and their impact on professional training through the fulfillment of academic activities of university students.

\section{Methodology}

It uses the deductive method, has a level of descriptive and explanatory research. For the descriptive analysis, the factorial and discriminant analysis is used; and for the explanatory analysis the regression analysis. The questionnaire was applied as an instrument for collecting information, with a Cronbach alpha index of 0.745. It is applied to a sample of 98 students from a population of 9197 of the National University of Chimborazo - Ecuador, through probabilistic sampling; the sample elements are the students of the Accounting and Audit Department.

For the application of the factorial, discriminant and regression analysis, variables were considered, such as: gender, age, marital status, frequency with which he drinks, alcoholic beverages consumed, frequency with which he drinks 6 or more drinks, frequency with which he does not can stop drinking, frequently with which he did not fulfill obligations, frequency with which he has needed to drink to recover, frequency due to guilt, frequency for not remembering the past to the next day, result of having hurt by effects of alcohol, some known worried about the consumption of drinks, preferred alcoholic beverage. These variables respond to general variables of: motivation, situations related to consumption, cognitive variables in relation to consumption, desire for drinking and loss of control, dependence, problems associated with the use of alcohol. Also used by different authors such as: Jimenez, Monasor and Rubio (2003), Valencia, González, and Galán (2014), Herrán and Ardilla (2009), Vera, Valdés, Martinez, and Carlos (2014), Vaca (2014), Albarracin and Muñoz (2008), as can be seen in the Table 4.

\section{Results and Discussion}

\subsection{Characterization of University Students.}

The results of the research show that $25 \%$ of the respondents are male and $75 \%$ are female; the ages are between 18 to 31 years, on average 20 years of age; likewise, $93.9 \%$ of respondents are single, $4.1 \%$ are married, $1 \%$ divorced and $1 \%$ is free. It is also observed that men in $52 \%$ drink beer and women in $55 \%$, came in $8 \%$ both women and men, likewise rum, instead vodka drink in $12 \%$ women and other drinks in a $36 \% \%$ males and $21 \%$ females, as can be seen in Table 2.

Table 2. Subject's gender-preferred alcoholic beverage cross-tabulation

\begin{tabular}{ccccccccc}
\hline & & \multicolumn{5}{c}{ Preferred alcoholic beverage } & \multirow{2}{*}{ Total } \\
\cline { 3 - 7 } & & Beer & Wine & Rum & Vodka & Other & \\
\hline \multirow{2}{*}{ Subject's gender } & Male & 52 & 8 & 4 & 0 & 36 & 100 \\
& Female & 55 & 8 & 4 & 12 & 21 & 100 \\
Total & & 54 & 8 & 4 & 9 & 24 & 100 \\
\hline
\end{tabular}

Source: Own elaboration based on questionnaire, 2019.

The type of beverages consumed by university students in general corresponds to $54 \%$ beer, $8 \%$ wine, $4 \%$ Rum, 9\% Vodka and 25\% others, as shown in Figure 2.

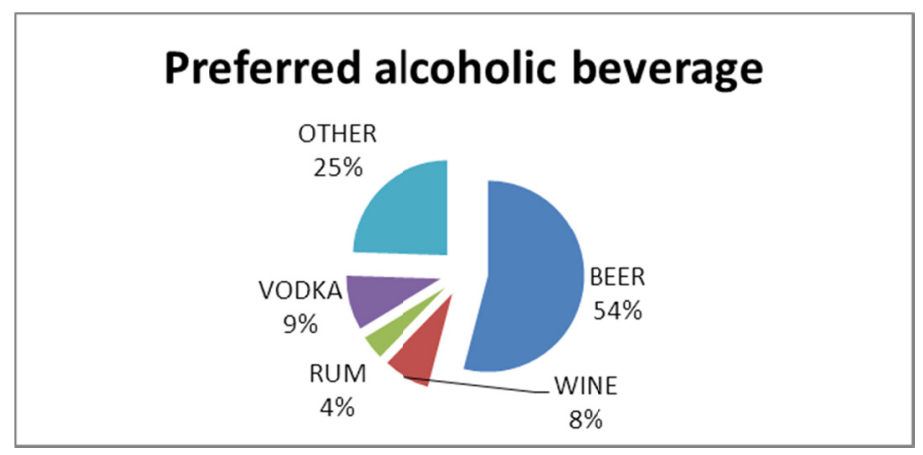

Figure 2. Type of alcoholic beverages consumed with preference by university students (Source: Own elaboration based on questionnaire, 2019) 
The frequency with which they consume alcoholic beverages in $41.8 \%$ is once a month, $20.4 \%$ two times a month, $9.2 \%$ two to 3 times a week, and $1 \%$ greater or equal to 4 times a week, as presented in Figure 3.

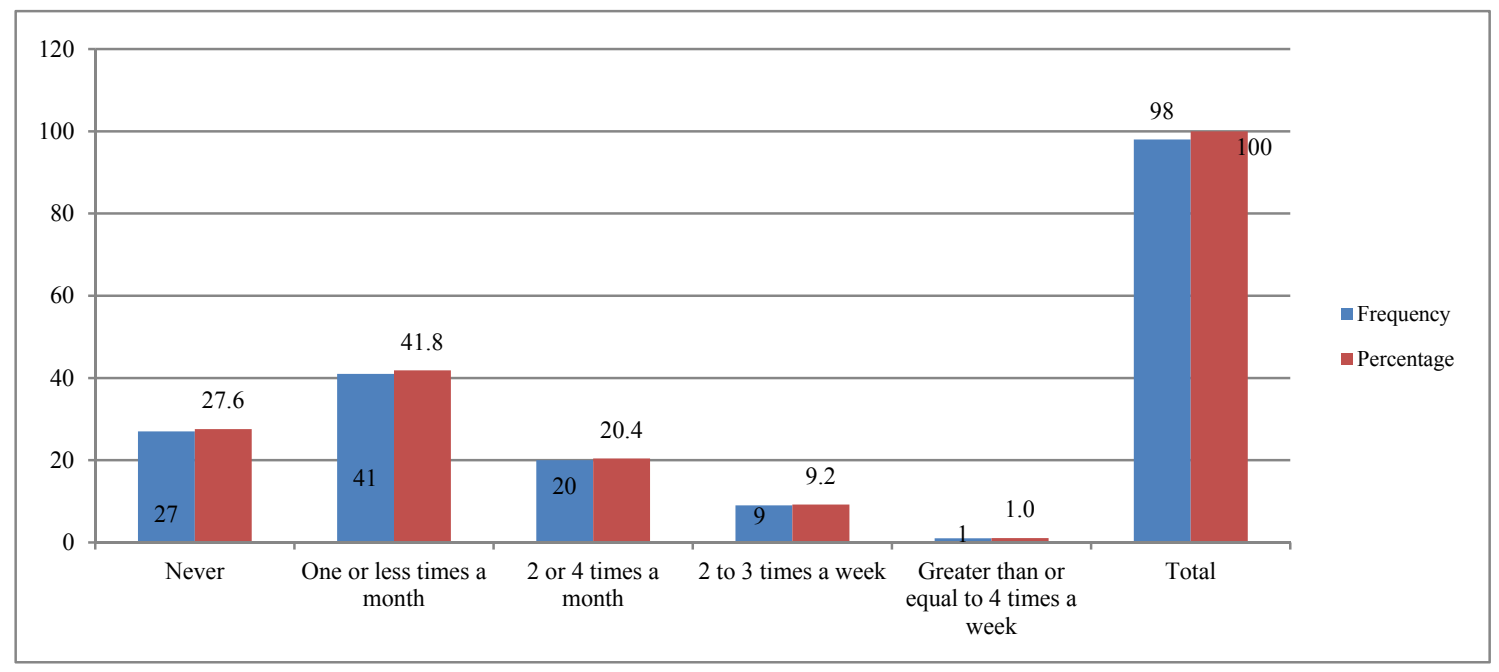

Figure 3. Frequency with which you drink alcoholic beverages (Source: Own elaboration based on questionnaire, 2019)

The results show that the age at which college students begin to consume alcohol is from 3.1 to 10 years old; from 13 to 15 of $13.3 \%$; 15 to 18 years of $52 \% ; 19$ to 21 years of $29.6 \%$ and 22 years ahead of $2 \%$, as presented in Table 3.

Table 3. Age of beginning to drink alcoholic beverage

\begin{tabular}{clcccc}
\hline & Frequency & Percentage & Valid Percentage & Accumulated Percentage \\
\hline \multirow{6}{*}{ Valid } & 3.0 & 3.1 & 3.1 & 3.1 \\
& $13-12$ & 13.0 & 13.3 & 13.3 & 16.3 \\
& $16-18$ & 51.0 & 52.0 & 52.0 & 68.4 \\
& $19-21$ & 29.0 & 29.6 & 29.6 & 98.0 \\
& 22 years and up & 2.0 & 2.0 & 2.0 & 100.0 \\
& Total & 98.0 & 100.0 & 100.0 & \\
\hline
\end{tabular}

Source: Own elaboration based on questionnaire, 2019.

It means that they begin to consume alcohol more frequently from 16 to 18 years of age; This confirms what was found by (Salcedo, Palacios, \& Espinosa, 2011, p 77) when he mentions that "the results indicate that alcohol consumption in university students begins in secondary school and is a problematic behavior"; that is to say, in the University, they initiate the alcohol consumption in the secondary one in a $52 \%$ and in a $29.6 \%$ in the university, which implies that a high probability of effects and academic, health and physiological consequences exists, as mentioned Castaño-Pérez and Calderón-Vallejo (2014, p. 6).

\subsection{Variables That Explain the Consumption of Alcohol in University Students}

According to studies carried out, they show a set of variables used to identify why they consume alcohol? the motivation? Positive or negative effects? What kind of associated problems? among others, and a set of instruments, as presented by Jimenez, Monasor, and Rubio (2003) in Table 4. 
Table 4. Instruments for measuring factors associated with alcohol consumption

\begin{tabular}{|c|c|}
\hline Variables & struments \\
\hline Motivation & $\begin{array}{l}\text { Drink profile (CDP, Miller and Marlatt, 1984). } \\
\text { Inventory of alcohol use (AUI, Horn et al., 1987). } \\
\text { Inventory of risk situations (IDS, Annis et al., 1987). } \\
\text { Drinking reasons questionnaire (RDQ, Heather et al., 1991). Drinking expectations questionnaire (AEQ, Brown et } \\
\text { al., 1980). Alcohol effects questionnaire (AEQ, Rohsenow, 1983). Alcohol beliefs questionnaire (ABQ, Collins) et } \\
\text { al., 1990). Questionnaire of expectations for drinking (AEQ-A, Brown et al., 1987). Scale of attitudes towards } \\
\text { alcohol in adolescents (AAST, Torabi and Veenker, 1986). } \\
\text { URICA (University of Rhode Island Change Assessment, Prochaska and Di Clemente, 1986). } \\
\text { SOCRATES (Stages of Change Readiness and Treatment Eagerness Scale; Miller, 1993). } \\
\text { The Questionnaire of readiness to change (RCQ, Rollnick et al., 1992). }\end{array}$ \\
\hline $\begin{array}{l}\text { Situations related to } \\
\text { consumption }\end{array}$ & $\begin{array}{l}\text { Inventory of drinking situations (IDS, Annis, 1982) } \\
\text { Inventory of precipitating relapse situations (RPI, Litman et al., 1977-88) } \\
\text { Beverage patterns questionnaire (Zitter and McCrady, 1979) }\end{array}$ \\
\hline $\begin{array}{l}\text { Cognitive variables in } \\
\text { relation to consumption }\end{array}$ & $\begin{array}{l}\text { The Questionnaire on Security in Situations (Situational Confidence Questionnaire, SCQ, Annis, 1982). } \\
\text { The Cognitive Assessment Questionnaire (Cognitive Appraisal Questionnaire, Annis, 1982). } \\
\text { The Inventory of coping skills (CBI, Litman et al., 1983) The inventory on the effectiveness of coping behaviors } \\
\text { (ECBI, Litman et al., 1983). } \\
\text { Alcohol expectations questionnaire (Alcohol Expectancy Questionnaire, Brown et al., 1980) } \\
\text { Alcohol Information Questionnaire (Maciá Antón, 1986) Alcohol Effects Scale (Alcohol Effects Scale, Southwick } \\
\text { et al., 1981). } \\
\text { Questionnaire on the effects of alcohol (Leigh, 1987). } \\
\text { Questionnaire on attitudes towards alcohol (Maciá Antón, 1986). }\end{array}$ \\
\hline $\begin{array}{l}\text { Desire for drink and loss } \\
\text { of control }\end{array}$ & $\begin{array}{l}\text { Alcohol Craving Questionnaire (Singleton et al., 1996). } \\
\text { Alcohol Craving Questionnaire-Now (ACQ-Now) (Singleton et al., 1995) Alcohol Urge Questionnaire (AUQ) } \\
\text { (Bohn et al 1995). } \\
\text { Penn Alcohol Craving Scale (PACS) (Flannery et al., 1999). } \\
\text { Desire for Alcohol Questionnaire (DAQ) (Clark et al., 1996). } \\
\text { Yale-Brown Obsessive Compulsive Scale for Heavy Drinking (Y-BOCS-hd) (Goldman et al., 1989). } \\
\text { Obsessive Compulsive Drinking Scale (OCDS) (Anton et al., 1995-96). }\end{array}$ \\
\hline Depe & $\begin{array}{l}\text { Alcohol dependence scale (ADS, Skinner and Horn, 1984). } \\
\text { Data on alcohol dependence (ADD, Raistrick et al., 1983) Severity of Alcohol Dependence Questionnaire (SADQ) } \\
\text { (Stockwell et al., 1979). } \\
\text { EIDA (Scale of Intensity of Alcoholic Dependence). }\end{array}$ \\
\hline $\begin{array}{l}\text { Problems associated } \\
\text { with the use of alcohol }\end{array}$ & $\begin{array}{l}\text { Rutgers Alcohol Problem Index (RAPI, White and Labouvie, 1989). } \\
\text { Index of problems due to drinking (DPI, Finney et al., 1991). } \\
\text { Inventory of consequences for drinking (DrInC, Miller et al., 1994) Questionnaire of problems for alcohol (APQ, } \\
\text { Williams and Drummond, 1994). }\end{array}$ \\
\hline $\begin{array}{l}\text { Interviews } \\
\text { multidimensional } \\
\text { instruments. }\end{array}$ & $\begin{array}{l}\text { Inventory on the use of alcohol (AUI, Horn et al., 1987) multidimensional } \\
\text { Severity Index of Addiction (ASI, McLellan et al., 1980). } \\
\text { European Addiction Severity Index (EuropASI) (Kokkevi and Hartgers, 1995, Bobes et al., 1996). } \\
\text { Comprehensive Drinking Profile (CDP, Miller and Marlatt, 1984) Program for the diagnosis of substance use } \\
\text { disorders (SUDDS, Harrison and Hoffman, 1989). } \\
\text { The structured addiction assessment interview to select the treatment (ASIST, Addiction Research Foundation, } \\
\text { 1984). } \\
\text { The essential-reactive alcoholism (ERA, Jacobson, 1976). } \\
\text { The interview for alcoholic subjects of Ellis (Ellis et al., 1988). } \\
\text { The Adolescent Drug Abuse Diagnostic Questionnaire (ADAD, Friedman and Utada, 1989). } \\
\text { The Adolescent Self-Assessment Profile (ASAP, Wanberg, 1991). } \\
\text { The Inventory of personal experiences (PEI, Winters and Henley, 1989). }\end{array}$ \\
\hline
\end{tabular}

Source: Jimenez, Monasor, and Rubio (2003, p. 25).

In this context, different authors use different measurement instruments on the causes, effects and consequences of alcohol consumption applied to different sectors of the population. In the case of research, consider the variables 
used by authors such as: Valencia, González, and Galán, (2014), Herrán and Ardilla (2009), Vera, Valdés, Martinéz, and Carlos (2014), Vaca (2014), and Albarracin and Muñoz (2008), being the common denominator of the variables to identify factors associated with alcohol consumption, such as: age, frequency, types, excessive consumption, intoxication, among other variables, as can be seen in the Table 5 .

Table 5. Variables measuring factors associated with alcohol consumption.

\begin{tabular}{|c|c|c|c|c|}
\hline $\begin{array}{c}\text { Valencia, } \\
\text { González, \& } \\
\text { Galán (2014) }\end{array}$ & $\begin{array}{l}\text { Herrán \& Ardilla } \\
\text { (2009) }\end{array}$ & $\begin{array}{c}\text { Vera, Valdés, } \\
\text { Martinéz, \& Carlos } \\
\text { (2014) }\end{array}$ & Vaca (2014) & Albarracin \& Muñoz (2008) \\
\hline Age & Age & $\begin{array}{l}\text { Intent to consume } \\
\text { through: }\end{array}$ & $\begin{array}{l}\text { Use of the Alcohol } \\
\text { Consumption Disorders } \\
\text { Identification Test } \\
\text { (AUDIT) }\end{array}$ & $\begin{array}{l}\text { Characteristics of place, frequency, quantity, } \\
\text { event of consumption and demographic data } \\
\text { and the Situational Inventory of Alcohol } \\
\text { Consumption. }\end{array}$ \\
\hline Frequency & Scholarship & $\begin{array}{c}\text { You know how to } \\
\text { prepare it and } \\
\text { consume it }\end{array}$ & Training & $\begin{array}{l}\text { 1) Unpleasant emotions, 2) Physical } \\
\text { discomfort, 3) Pleasant emotions, 4) Testing } \\
\text { self-control and 5) Urgency to consume. }\end{array}$ \\
\hline Types & $\begin{array}{l}\text { Socioeconomic } \\
\text { level }\end{array}$ & Get easily & Employment situation & $\begin{array}{l}\text { The second group measures Situations that } \\
\text { involve third parties, it is divided into three } \\
\text { categories: 1) Conflict with others, 2) Social } \\
\text { pressure and 3) Pleasant moments. }\end{array}$ \\
\hline $\begin{array}{l}\text { Excessive } \\
\text { consumption }\end{array}$ & $\begin{array}{l}\text { Taste for the } \\
\text { drinking }\end{array}$ & Acquire without risk & Family composition & \\
\hline \multirow[t]{5}{*}{ Intoxication } & Frequency & $\begin{array}{l}\text { Sure you are not } \\
\text { going to get drunk }\end{array}$ & $\begin{array}{l}\text { Leisure activities and } \\
\text { free time }\end{array}$ & \\
\hline & $\begin{array}{l}\text { Problematic } \\
\text { consumption }\end{array}$ & Overcome insecurity & Parental control & \\
\hline & Alcohol risk & $\begin{array}{l}\text { Release the } \\
\text { pressures }\end{array}$ & Start age of & \\
\hline & & $\begin{array}{c}\text { Rrelieve your } \\
\text { sorrows } \\
\end{array}$ & $\begin{array}{c}\text { Place of acquisition and } \\
\text { consumption } \\
\end{array}$ & \\
\hline & $\begin{array}{c}\text { (Del Pino \& } \\
\text { Correa, 2016) }\end{array}$ & $\begin{array}{l}\text { Do different things } \\
\text { and have the } \\
\text { acceptance of your } \\
\text { friends }\end{array}$ & $\begin{array}{l}\text { Companions, perception } \\
\text { or risk. }\end{array}$ & \\
\hline
\end{tabular}

Considering these factors, the research used as variables of measurement of alcohol consumption in university students: Gender of the subject, Age of the subject, Marital status, Frequency of drinking, Alcoholic beverages consumed, Frequency of drinking 6 or more drinks, Age of beginning to drink, Alcoholic beverage. These variables are considered for the application of a linear regression model in order to identify the causes of alcohol consumption in university students of the National University of Chimborazo. The regression model is represented as follows:

$$
Y=a+b_{1} X_{1}+b_{2} X_{2}+\ldots b_{n} X_{n}
$$

Where:

Alcoholic beverages consumed $=a+b_{1}($ age $)+b_{2}$ (marital status) $+b_{3}$ (frequency) $+b_{4}$ (frequencies of drinking more than 6 drinks) $+b_{5}$ (age of beginning to drink) $+b_{6}$ (preferred beverage)

The results of the investigation show the following descriptive statistics (see Table 6): 
Table 6. Descriptive statistics

\begin{tabular}{lccccc}
\hline Variable & N & Minimum & Maximum & Average & Standard deviation \\
\hline Gender of the subject & 98 & 1 & 2 & 1.74 & 0.438 \\
Age of the subject & 98 & 18 & 31 & 20.55 & 2.311 \\
Marital status & 98 & 1 & 5 & 1.11 & 0.535 \\
Frequency of drinking & 98 & 1 & 5 & 2.14 & 0.963 \\
Alcoholic beverages consumed & 98 & 1 & 5 & 1.81 & 1.100 \\
Frequency of drinking 6 or more drinks & 98 & 1 & 5 & 1.80 & 0.994 \\
Age of beginning to drink & 98 & 1 & 5 & 3.14 & 0.786 \\
Preferred alcoholic beverage & 98 & 1 & 5 & 2.42 & 1.735 \\
N valid (per list) & 98 & & & & \\
\hline
\end{tabular}

Source: Elaboration based on data from the applied questionnaire, 2018.

The results of the application of the linear regression model, show in model 1, that there is a significant relationship between the variables in a $(\mathrm{R}=0.761) 76.10 \%$ and explain the alcohol consumption variables such as: age, gender, marital status and the type of alcoholic beverage, its frequency of consumption and if the frequency is greater than 6 drinks, age of beginning to drink and preferred drinks in one $(\mathrm{R} 2=0.58) 58 \%$. However, observing the degree of significance of each variable in the explanation to the dependent variable (see Table 2), it is identified that age does not have a significant contribution; which means that if it is considered part of the variables or not, it is not very important. Under this concept, the age variable was removed; considering that the adjusted $\mathrm{R}$ value is 0.547 , which show that when removing or increasing the age variable, the changes are not very significant, which allows applying model 2 .

The results of Model 2 show that the variables that explain the consumption of alcohol by university students reaches $57.2 \%(\mathrm{R} 2=0.572)$ and a correlation of $75.6 \%(\mathrm{R}=0.756)$. However, to observe what the degree of explanation is with the variables related to the frequencies of consumption and frequency of drinking more than 6 drinks? The results of the model show that there are two variables that explain $50.2 \%$. $(\mathrm{R} 2=0.502)$ and there is a dependency correlation of $70.8 \%(\mathrm{R}=0.708$ as presented in Table 3$)$. This means that by modifying model 2 to model 3 , the degree of explanation decreases significantly and the correlation between independent and dependent variables in the same way.

Therefore, the optimal model could be Model 2, showing that $\mathrm{H} 1$ alcohol consumption in university students depends mainly on the subject's gender, age of beginning to drink, marital status, frequency of drinking, frequency of drinking 6 or more drinks (ANOVA $=., 00$ ), being the variables of greater explanation: Frequency of drinking 6 or more drinks, frequency of drinking an alcoholic beverage (see Table 7).

Table 7. Summary of model ${ }^{b}$

\begin{tabular}{|c|c|c|c|c|c|c|c|c|c|}
\hline \multirow[b]{2}{*}{$\begin{array}{l}\text { b, Variable: Alcoholic } \\
\text { consumed }\end{array}$} & \multirow[b]{2}{*}{$\mathrm{R}$} & \multirow[b]{2}{*}{ R square } & \multirow[b]{2}{*}{$\begin{array}{l}\mathrm{R} \text { snug } \\
\text { squared }\end{array}$} & \multirow[b]{2}{*}{$\begin{array}{c}\text { Standard } \\
\text { error of the } \\
\text { estimate }\end{array}$} & \multicolumn{3}{|c|}{ Change statitics } & \multirow[b]{2}{*}{$\begin{array}{l}\text { Durbin-W } \\
\text { atson }\end{array}$} & \multirow[b]{2}{*}{ ANOVA } \\
\hline & & & & & $\begin{array}{c}\text { Change } \\
\text { of } R \\
\text { square }\end{array}$ & $\begin{array}{l}\text { Change } \\
\text { in } \mathrm{F}\end{array}$ & $\begin{array}{c}\text { Sig. } \\
\text { Chang } \\
\text { e in } F\end{array}$ & & \\
\hline $\begin{array}{l}\text { GENERAL MODEL a. frequency of } \\
\text { drinking, preferred alcoholic beverage, } \\
\text { age of beginning to drink, gender of the } \\
\text { subject, marital status, age of the } \\
\text { subject, frequency of drinking } 6 \text { or more } \\
\text { drinks. }\end{array}$ & $0.761^{\mathrm{a}}$ & 0.580 & 0.547 & 0.740 & 0.580 & 17.744 & 0.000 & 2.314 & 0.000 \\
\hline A. Gender of the subject & $0.146^{\mathrm{a}}$ & 0.021 & 0.011 & 1.094 & 0.021 & 2.105 & 0.150 & 2.162 & 0.150 \\
\hline A. Age of the subject & $0.002^{\mathrm{a}}$ & 0.000 & -0.010 & 1.105 & 0.000 & 0.000 & 0.985 & 2.139 & 0.985 \\
\hline A. Marital status & $0.107^{\mathrm{a}}$ & 0.012 & 0.001 & 1.099 & 0.012 & 1.121 & 0.292 & 2.094 & 0.292 \\
\hline A. Frequency of drinking & $0.571^{\mathrm{a}}$ & 0.327 & 0.319 & 0.907 & 0.327 & 46.540 & 0.000 & 2.351 & 0.000 \\
\hline $\begin{array}{l}\text { A. Frequency of drinking } 6 \text { or more } \\
\text { drinks }\end{array}$ & $0.708^{\mathrm{a}}$ & 0.502 & 0.496 & 0.780 & 0.502 & 96.581 & 0.000 & 2.421 & 0.000 \\
\hline A. Preferred alcoholic beverage & $0.032^{\mathrm{a}}$ & 0.001 & -0.009 & 1.105 & 0.001 & 0.099 & 0.753 & 2.157 & 0.753 \\
\hline A. Age of beginning to drink & $0.254^{\mathrm{a}}$ & 0.064 & 0.055 & 1.069 & 0.064 & 6.604 & 0.012 & 20010 & 0.120 \\
\hline
\end{tabular}




\section{MODEL 2}

Gender of the subject, age of beginning

to drink, marital status, frequency of

drinking, frequency of drinking 6 or

$0.756^{\mathrm{a}} \quad 0.572 \quad 0.549$

0.739

0.572

24.577

0.000

2.289

0.000

more drinks.

MODEL 3.

Frequency of drinking 6 or more drinks, $\quad 0.70$

0.502

0.491

0.785

0.502

47.788

0.000

2.421

0.000

frequency of drinking.

Source: Elaboration based on data from the applied questionnaire, 2018.

This means that there are behavioral factors that are the cause of alcohol consumption and age is not a determining factor for alcohol consumption in university students.

\subsection{Social and Economic Factors Associated With Alcohol Consumption}

It was also important to determine what type of social and economic factors are associated with alcohol consumption? Studies conducted on the factors associated with alcohol consumption, show that there are risk factors associated with the behavior of alcohol intake, such as those mentioned by some authors that are in Table 4 . These factors are related to:

The lack of control of the establishments where young people attend, the low parental regulations, the flexibility of legal control, the ease of acquisition of liquor and other substances, as well as the lack of strategies that address the importance of liquor consumption from its singularity (Betancourth, Tacán, \& Cordova, 2017, p.48).

Also, authors such as Méndez \& Azustre (2017) show that there are social and academic factors, when they mention, that:

It has been found that the causes that led to the consumption of alcohol in college students had very close values between the different variables presented, although they highlighted slightly those that affected a distance from the family, aggressiveness, anxiety and decreased academic performance, others such as loss of general interest, negative changes in hygiene, personal appearance or defensive attitude. Also, it is observed that the frequency of consumption of alcoholic beverages is quite high, both low and high, concentrating the consumption of the latter during the weekends. Among the reasons for consumption are labor problems and academic demands, without forgetting its high social component, very widespread in our culture and that, in these ages, is a facilitator of interpersonal relationships among equals (I disinhibited and can make friends more easily) (p.701).

On the other hand, Barradas, Fernández, and Gutiérrez (2016, p. 2) mentions that "the factors associated with consumption are related to the level of consumption and risk"; for Castaño, García, and Marzo (2014, p. 52) are the "expectations, beliefs, publicity, family and social customs, have a favorable relationship for alcohol consumption in university students in Medellín, Colombia; for Albarracin \& Muñoz $(2008$, p. 60) are associated with pleasant emotions and social pressure mainly, and for Castaño and Calderon $(2014$, p. 741) are associated with sociodemographic factors such as "age, gender, state civil and socioeconomic level ".

In this context, in order to determine the social and economic factors that are associated with alcohol consumption in university students at the UNACH, multivariate analysis was used through the factoring model, where the model considers 15 variables initially. The results of the Kaiser-Meyer-Olkin index (MKO), show an MKO $=0.73$; it means that it is appropriate to perform a factorial analysis to identify factors that characterize university consumers of alcoholic beverages.

The results of the factorization show that in the first model it was possible to group in five factors that explain $68.57 \%$; On the other hand, when they are of 6 factors, this explains $8.01 \%$, which is significant. Therefore, the factor model with the best explanation is that of 6 factors. However, this explanation by removing three variables that are not significant, such as the following variables: Frequency for not remembering the past $(49.1 \%)$, some known about the consumption of beverages (50\%) and preferred alcoholic beverage (57.4\%). That is, apply the model with 12 factors, the factors explained to reduce by 6 factors in $84.71 \%$, improving the explanation of each variable, as seen in Table 8 . 
Table 8. Results of the factorial model

\begin{tabular}{|c|c|c|c|c|c|c|c|c|c|c|c|c|c|c|}
\hline \multicolumn{3}{|c|}{ Communalities } & \multicolumn{6}{|c|}{ Component } & \multicolumn{6}{|c|}{ Rotated Component } \\
\hline & $\begin{array}{c}\text { Ext. } \\
\text { Inicial }\end{array}$ & Extraction & 1 & 2 & 3 & 4 & 5 & 6 & 1 & 2 & 3 & 4 & 5 & 6 \\
\hline $\begin{array}{c}\text { Gender of the } \\
\text { subject }\end{array}$ & 0.819 & 0.907 & -0.342 & -0.475 & 0.070 & -0.080 & -0.271 & 0.693 & -0.134 & -0.050 & -0.111 & -0.087 & 0.928 & -0.068 \\
\hline $\begin{array}{c}\text { Age of the } \\
\text { subject }\end{array}$ & 0.788 & 0.805 & 0.038 & 0.780 & 0.270 & 0.052 & 0.088 & 0.335 & 0.098 & -0.020 & 0.843 & 0.129 & -0.028 & 0.259 \\
\hline Marital status & 0.737 & 0.805 & -0.097 & 0.652 & 0.506 & -0.264 & -0.209 & 0.045 & -0.102 & -0.015 & 0.843 & -0.141 & -0.088 & -0.236 \\
\hline $\begin{array}{c}\text { Frequency of } \\
\text { drinking } \\
\end{array}$ & 0.811 & 0.839 & 0.810 & -0.212 & 0.152 & -0.184 & 0.270 & 0.085 & 0.396 & 0.814 & -0.104 & -0.007 & -0.086 & 0.051 \\
\hline $\begin{array}{l}\text { Alcoholic } \\
\text { beverages } \\
\text { consumed } \\
\end{array}$ & 0.854 & 0.852 & 0.588 & -0.204 & 0.656 & -0.070 & 0.168 & -0.048 & -0.058 & 0.875 & 0.109 & 0.140 & -0.091 & -0.210 \\
\hline $\begin{array}{l}\text { Frequency of } \\
\text { drinking } 6 \text { or } \\
\text { more drinks }\end{array}$ & 0.889 & 0.901 & 0.798 & -0.286 & 0.301 & -0.082 & 0.227 & 0.185 & 0.309 & 0.885 & 0.073 & 0.119 & 0.049 & 0.005 \\
\hline $\begin{array}{l}\text { Frequency } \\
\text { with which it } \\
\text { cannot stop } \\
\text { drinking. }\end{array}$ & 0.851 & 0.884 & 0.847 & 0.177 & -0.237 & -0.190 & -0.180 & -0.104 & 0.811 & 0.312 & 0.015 & -0.003 & -0.307 & -0.186 \\
\hline $\begin{array}{l}\text { Frequency } \\
\text { with which it } \\
\text { did not fulfill } \\
\text { obligations. }\end{array}$ & 0.828 & 0.839 & 0.790 & 0.134 & -0.385 & -0.166 & -0.046 & -0.140 & 0.796 & 0.249 & -0.115 & -0.038 & -0.356 & -0.037 \\
\hline $\begin{array}{c}\text { Frequency } \\
\text { with which it } \\
\text { has needed to } \\
\text { drink to } \\
\text { recover. }\end{array}$ & 0.713 & 0.768 & 0.564 & 0.144 & -0.399 & -0.047 & -0.277 & 0.437 & 0.835 & 0.040 & 0.063 & 0.080 & 0.240 & 0.032 \\
\hline $\begin{array}{l}\text { Frequency by } \\
\text { feeling guilty. }\end{array}$ & 0.702 & 0.737 & 0.709 & 0.154 & -0.134 & 0.424 & -0.082 & 0.075 & 0.589 & 0.228 & 0.013 & 0.560 & -0.152 & 0.040 \\
\hline $\begin{array}{c}\text { Result of } \\
\text { having injured } \\
\text { by the effects } \\
\text { of alcohol. }\end{array}$ & 0.781 & 0.897 & 0.284 & -0.017 & 0.227 & 0.863 & -0.141 & -0.012 & -0.009 & 0.098 & -0.014 & 0.938 & -0.036 & -0.079 \\
\hline $\begin{array}{c}\text { Age of } \\
\text { beginning to } \\
\text { drink. }\end{array}$ & 0.928 & 0.931 & -0.217 & 0.232 & -0.339 & 0.126 & 0.793 & 0.267 & -0.083 & -0.101 & 0.016 & -0.070 & -0.061 & 0.951 \\
\hline
\end{tabular}

Frequency for

$$
\text { not }
$$

remembering $\quad 0.491$

what happened

the next day.

Some familiar

worried about

the

0.500

consumption

of beverages.

\section{Preferred}

alcoholic

0.574

beverages.
Rotation method: Varimax with Kaiser standardization.

Source: Elaboration based on data from the applied questionnaire, 2018. 
Thus, the factors that explain the consumption of alcohol are: Factor of 1 Academic risk factor: Frequency with which it cannot stop drinking, frequency with which it did not fulfill obligations, frequency with which it has needed to drink to recover, frequency by feeling guilty, these factors explain $21.96 \%$; Factor 2 Economic risk factor, represented by: frequency of drinking, alcoholic beverages consumed, frequency of drinking 6 or more drinks, which explain 20.39\%; Factor 3 Demographic factor: represented by: age of the subject, marital status, explain 12.32\%; Factor 4 Social factor: represented by: result of having injured by effect and explain 10.70\%; Factor 5 generational factor, represented by: Gender of the subject that explain 9.96\%; Factor 6 Dependence factor, represented by: Age of beginning to drink that explain $9.36 \%$, with a total explanation of $84.71 \%$. This means that there are social and economic factors that are associated with alcohol consumption by university students, demonstrating H2. However, it is also identified that there are generational, dependency, academic and demographic factors.

\subsection{Academic Noncompliance as an Effect of Alcohol Consumption in University Students}

As an effect of the linear regression analysis and the factorial model, it can be identified that there are factors associated with academic activity in university students who consume alcohol. It is known that the changes in cultural and social customs, information technologies and the influence of the media have been the most incidents in alcohol consumption by adolescents and early youth, stages in which young people they are vulnerable for the consumption of any type of substance, life schemes that in recent years have been modified by the ease of access and availability of mixed alcoholic beverages with different flavors, as well as the design in their presentation that attract girls and boys Another factor is advertising about alcohol that is presented in the media, in sports venues, in places of entertainment, are among the main factors that influence that drinking is a habit for young people.

Studies have shown that the effects of alcohol consumption in young people are related to human physiology. Estruch (2002), states that alcohol produces a series of diseases associated with moderate and compulsive consumption of alcoholic beverages such as: effects on the digestive system, the cardiovascular system, the nervous system, alcohol consumption has an addictive dependence similar to other drugs, where this can generate indirect consequences in the human being such as: traffic accidents, violent behavior, absenteeism, low performance, possible risks of work accidents, among others. Other effects, is learning, is related to absenteeism and neglect of abuse, school dissatisfaction, school repetition, unwanted pregnancies, sexually transmitted diseases and mental, family and social problems, in addition to these difficulties also cause in compulsive alcohol drinkers greater difficulty in the teaching-learning process, they are easily distracted, they retain and remember less information, they decrease academic performance, they alter behavior and behavior of students, they fail to perform tasks (Castaño-Pérez \& Calderón-Vallejo, 2014, p. 6).

Another effect is related to public health, Ahumada-Cortéz, Gámez-Medina, and Vladez-Montero (2017, pp. 15-18) stresses that the risk factors for alcohol consumption are related to: biological, personal, family factors, psychological, school, environmental and social, each factor has a significant impact on the individual, and positively or negatively influence consumption. Health problems as a result of alcohol consumption are directly related to 60 chronic diseases, classified as follows: Cardiovascular disorders, Digestive disorders, Haematological disorders, Musculoskeletal disorders, metabolic disorders, endocrine disorders, infections, cancer, Neurological disorders.

To identify if there are explanatory factors in the fulfillment of academic activities such as alcohol effects that affect the learning process and university professional training, discriminant and linear regression analysis is applied.

The results of the discriminant analysis show that there are three groups. The most discriminating factor in group 1 are those students who cannot stop drinking alcohol frequently $(\mathrm{R} 2=0.748)$; in group 2 , those students who frequently feel guilty about consuming alcohol $(\mathrm{R} 2=0.859)$; and in group 3 , those who have a preferred alcoholic beverage $(\mathrm{R} 2=0.706)$. Likewise, there is a high probability that those students who did not fulfill their academic obligations will not do so (94.8\%); those who at least once did not meet their academic obligations $60 \%$ may repeat the same and $26.7 \%$ will not do it; and those who do not meet their academic obligations every month will probably do it again in $66.7 \%$ and never in $33.3 \%$; showing the $\mathrm{H} 3$.

From the results of the discriminant analysis the linear regression model was applied, considering as explanatory variables: (x1) with frequencies they cannot stop drinking alcohol, $(\mathrm{x} 2)$ they have a feeling of guilt for consuming alcohol and (x3) those who have a preferred alcoholic beverage; and as a variable explained (and) non-compliance with academic activities; In order to know the effect and verify what impact it has on the fulfillment of academic activities in university students and this in professional training.

The results of the linear regression application show that there is a high correlation between the variables of $82.1 \%$ 
$(\mathrm{R}=0.821)$ and explain these variables in $67.4 \%(\mathrm{R} 2=0.674)$, as shown in Table 9. This means, that the fulfillment of academic activities in students who consume alcohol depends on the frequencies with which they cannot stop drinking alcohol in $81.2 \%(\mathrm{R}=0.812)$, who have a feeling of guilty for consuming alcohol in $0.83 \%(\mathrm{R}$ $=0.083)$ and that they have a preferred alcoholic beverage at $5.23 \%(\mathrm{R}=0.523)$, contrasting the H4. Likewise, it represents that alcohol consumption in university students affects vocational training, because "it is understood that reference is being made to a type of training whose main purpose is to prepare people for work" (Casanova, 2003 , p. 7) and failing to comply with the obligations of the student, mainly that which refers to "Perform properly and timely work, research, university extension and curricular activities and take the assessment tests inherent to the academic year" (UNACH, 2018, p. 11); since the student must comply with what is mentioned in Art. 13 and mainly the numeral 4 "Comply with responsibility, ethics and academic rigor all the obligations derived from his student status" (UNACH, 2018, p. 12), as well as the Art. 5.

Table 9. Summary of model ${ }^{b}$

\begin{tabular}{|c|c|c|c|c|c|c|c|c|}
\hline \multirow[b]{2}{*}{ Model } & \multirow[b]{2}{*}{$\mathrm{R}$} & \multirow[b]{2}{*}{$\begin{array}{c}\mathrm{R} \\
\text { square }\end{array}$} & \multirow[b]{2}{*}{$\begin{array}{l}\text { R snug } \\
\text { square }\end{array}$} & \multirow[b]{2}{*}{$\begin{array}{l}\text { Standard error } \\
\text { of the estimate }\end{array}$} & \multicolumn{3}{|c|}{ Estadísticas de cambios } & \multirow[b]{2}{*}{ Anova } \\
\hline & & & & & $\begin{array}{l}\text { Change of } \\
\text { square of } R\end{array}$ & $\begin{array}{c}\text { Change } \\
\text { in } \mathrm{F}\end{array}$ & $\begin{array}{c}\text { Sig. } \\
\text { Change in } \\
\text { F }\end{array}$ & \\
\hline 1 General & $0.821^{\mathrm{a}}$ & 0.674 & 0.664 & 0.394 & 0.674 & 64.773 & 0.000 & $.000^{\mathrm{b}}$ \\
\hline Frequency with which it cannot stop drinking. & 0.812 & 0.659 & 0.655 & 0.399 & 0.659 & 185.344 & 0.000 & 0.000 \\
\hline Age of beginning to drink. & 0.083 & 0.007 & -0.004 & 0.681 & 0.007 & 0.660 & 0.41 & 0.418 \\
\hline Frequency by feeling guilty. & 0.523 & 0.273 & 0.266 & 0.582 & 0.273 & 36.140 & 0.000 & 0.000 \\
\hline
\end{tabular}

a. Predictors: (Constant), Frequency with which it cannot stop drinking, age of beginning to drink, frequency by feeling guilty.

b. Dependent variable: Frequency with which it did not fulfill obligations.

Source: Elaboration based on data from the applied questionnaire, 2018.

\section{Conclusions}

It is shown that alcohol consumption in university students depends mainly on the subject's gender, age of beginning to drink, marital status, frequency of drinking, frequency of drinking 6 or more drinks, determining that two variables are the ones he has greater weight, such as: the frequency of drinking 6 or more drinks and the frequency of drinking an alcoholic beverage.

It is identified that there are academic factors, such as: the frequency with which it cannot stop drinking, frequency with which it did not fulfill obligations, frequency with which it has needed to drink to recover, frequency by feeling guilty; economic factors, such as: the frequency of drinking, alcoholic beverages consumed, frequency of drinking 6 or more drinks, demographic factors, such as: the age of the subject, marital status; social factors, such as: having hurt by effect, generational factors, such as: Gender of the subject, factors of dependence, such as: age of beginning to drink, are those that determine the consumption of alcohol in university students.

It is demonstrated that there is a high probabilistic incidence of alcohol consumption in the degree of fulfillment of academic obligations. And the degree of compliance depends a lot on the effects of consumption such as: the fault for consuming alcohol and the preference for an alcoholic beverage.

\section{References}

Ahumada-Cortéz, J. G., Gámez-Medina, M. E., \& Vladez-Montero, C. (2017). El consumo del alcohol como problema de salud pública. Ra Ximhai, 13(2), 13-24. https://doi.org/10.35197/rx.13.02.2017.01.ja

Alban, J. (2016). Consumo de alcohol y rendimiento académico en los y las estudiantes de la Escuela. Ecuador: I congreso online sobre la educación en el Siglo XXI. Retrieved from http://www.eumed.net/libros-gratis/actas/2016/educacion/jjao.pdf

Albarracin, M., \& Muñoz, L. (2008). Factores asociados al consumo del alcohol en estudiantes de los dos primeros años de carrera universitaria. Revista Liverabit, 14, 49-61. Retrieved from http://www.scielo.org.pe/pdf/liber/v14n14/a07v14n14

Alonso, A., \& Correa, B. (2016). Alcoholismo en jóvenes universitarios de diferentes carreras. Psicología Cientifica, 1-9. Retrieved from https://es.scribd.com/document/340366264/Alcoholismo-en-JovenesUniversitarios-de-Diferentes-Carreras\# 
Barradas, M., Fernández, N., \& Gutiérrez, L. (2016). Prevalencia de consumo de alcohol en estudiantes universitarios. Revista Iberoamericana para la Investigación y el Desarrollo Educativo, 6(12), 1-14. https://doi.org/10.23913/ride.v6i12.213

Betancourth, S., Tacán, L., \& Cordova, E. (2017). Consumo de alcohol en estudiantes universitarios colombianos. Revista Universidad y Salud, 19(1), 37-50. https://doi.org/10.22267/rus.171901.67

Castaño, G., García, J., \& Marzo, J. (2014). Consumo de alcohol y factores intervinientes en estudiantes universitarios. Revista Cubana de Salud Pública, 40(1), 47-54. Retrieved from $\mathrm{http} / / /$ scielo.sld.cu/scielo.php?script=sci_arttext\&pid=S0864-34662014000100006

Castaño-Pérez, G. A., \& Calderón-Vallejo, G. A. (2014). Problemas asociados al consumo de alcohol en

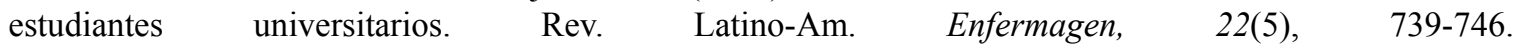
https://doi.org/10.1590/0104-1169.3579.2475

Estruch, R. (2002). Efectos del alcohol en la fisiología humana. Adicciones, 14, 19. https://doi.org/10.20882/adicciones.519

Freire, W. B., Ramírez, M. J., Belmont, P., Mendieta, M. J., Silva, M. K., Romero, N., \& Sáenz, K. (2013). RESUMEN EJECUTIVO. TOMO I. Encuesta Nacional de Salud y Nutrición. Ecuador: Ministerio de Salud Pública/Instituto Nacional de Estadística y Censos. Retrieved from https://www.paho.org/ecu/index.php? option=com_docman\&view=download\&category_slug=vigilancia-sanitaria-y-atencion-de-las-enfermedade s\&alias=452-encuesta-nacional-de-salud-y-nutricion\&Itemid

Herrán, O., \& Ardilla, M. (2009). Alcohol consumido y variables asociadas en Bucaramanga, Colombia. Revista Chilena de nutrición, 36(3), 217-226. https://doi.org/10.4067/S0717-75182009000300004

Hingson, R., Heeren, T., \& Winter, M. (2006). Age at drinking onset and alcohol dependence: Age at onset, duration, and severity. Arch Pediatr Adolesc Med., 160(7), 739-746. https://doi.org/10.1001/archpedi.160.7.739

Jimenez, M., Monasor, R., \& Rubio, G. (2003). Instrumentos de evaluación en el alcohol. Revista Transtornos Adictivos, 5(1), 13-21. https://doi.org/10.1016/S1575-0973(03)70101-9

López, J., \& Morales, F. (2018). Consumo de tabaco y alcohol en estudiantes universitarios de enfermería de una institución pública del estado de Puebla, México. Revista Facultad de Ciencias de la Salud UDES, 5(1), 8-13. https://doi.org/10.20320/rfcsudes.v5i1.101

López-Vásquez, J. A., Pacheco-Hernández, K. P., Tenahua-Quitl, I., \& Torres-Roldan, A. M. (2017). Motivos y tipos de consumo de alcohol en estudiantes universitarios de enfermería. Revista Nure, 14(87), 1-7. Retrieved from http://www.nureinvestigacion.es/OJS/index.php/nure/article/view/1067/746

Méndez, J., \& Azustre, M. (2017). El consumo de alcohol en universitarios. Estudio de las relaciones entre las causas y los efectos negativos. Revista Complutense de Educación, 28(3), 689-704. https://doi.org/10.5209/rev_RCED.2017.v28.n3.49725

Míguez, M., \& Permuy, B. (2017). Características del alcoholismo en mujeres. Revista de la Facultad deMedicina, 65(1), 15-22. https://doi.org/10.15446/revfacmed.v65n1.57482

Rodríguez, L. (2017). Factores explicativos y consecuencias del consumo de alcohol en estudiantes universitarios. Universidad de Santiago de Compostela. Tesis doctoral. Retrieved from https://minerva.usc.es/xmlui/bitstream/handle/10347/15298/rep_1346.pdf?sequence=1\&isAllowed=y

Rubio, A. (2016). Consumo de alcohol y contextos de desarrollo en la adolescencia. Obtenido de Consumo de alcohol y contextos de desarrollo en la adolescencia. Universidad de Huelva. Tesis Doctoral Retrieved from http://www.codajic.org/sites/www.codajic.org/files/Consumo\%20de $\% 20$ alcohol $\% 20 \mathrm{y} \% 20$ contextos $\% 20 \mathrm{de}$ $\% 20$ desarrollo\%20en\%201a\%20adolescencia\%20.pdf

Salcedo, A., Palacios, X., \& Espinosa, A. (2011). Consumo de alcohol en jóvenes universitarios. Revista Avances en Psicología Latinoamericana, 29(1), 77-97. Retrieved from http://www.scielo.org.co/pdf/apl/v29n1/ v29n1a07.pdf

Sánchez, C. (2018). Conducta resiliente y abuso de alcohol en estudiantes de Psicología de la UMSA. Revista de Investigación Psicológica, 20,11-27. Retrieved from http://www.scielo.org.bo/scielo.php?script=sci_arttext \&pid=S2223-30322018000200003\&lng=es\&tlng=es

UNACH. (2018). Codigo de ética. Riobamba, UNACH. Retrieved from http://www.unach.edu.ec/images/pdf/ 2018_reglamento/codigo_de_Etica.pdf 
UNACH. (2018). Guia estudiantil. Riobamba, UNACH. Retrieved from www.unach.edu.ec/wp-content/ estudiantes/Guia\%20del\%20Estudiante_definitiva.compressed.pdf

Vaca, S. E. (2014). Variables psicosociales y consumo de alcohol en adolescentes de Loja y Zamora. Informe de Investigación. Universidad Técnica Particulas de Loja. Retrieved from https://smartland.utpl.edu.ec/sites/ default/files/Informe_final_de_investigacion_sobre_el_alcoholismo_en_los_jovenes.pdf

Valencia, J., González, M. J., \& Galán, I. (2014). Aspectos metodológicos en la medición del consumo de alcohol: la importancia de los patrones de consumo. Revista Española de Salud Pública, 4, 433-446. https://doi.org/10.4321/S1135-57272014000400002

Vargas-Martínez, A. M., Trapero-Bertran, M., Gil-García, E., \& Lima-Serrano, M. (2018). Impacto del consumo episódico excesivo de alcohol en la adolescencia. $\measuredangle$ Lo estamos haciendo bien?. Adicciones, 30(2), 152-154. https://doi.org/10.20882/adicciones.1033

Vera, J., Valdés, A., Martinéz, L., \& Carlos, E. (2014). Modelo de medición de la intención de consumo de alcohol en adolescentes. Revista Interamericana de Psicología, 48(2), 315-327. Retrieved from https://www.redalyc.org/html/284/28437897008

Vila, M. (2018). Rendimiento cognitivo en adolescentescon abuso de alcohol e Internet. Universidad Miguel Hernández de Elche. Tesis doctoral. Retrieved from http://dspace.umh.es/bitstream/11000/4525/1/ TD\%20Mar\%C3\%ADn\%20Vila\%2C\%20Maria.pdf

\section{Copyrights}

Copyright for this article is retained by the author(s), with first publication rights granted to the journal.

This is an open-access article distributed under the terms and conditions of the Creative Commons Attribution license (http://creativecommons.org/licenses/by/4.0/). 